\title{
DESIGN AND IMPLEMENTATION OF A MODIFIABLE CLOSED-LOOP CONTROL SYSTEM FOR DC TO DC VOLTAGE REGULATION
}

\section{Bereš, D. Ženčuch}

Technical University of Košice

Letná, 9, Košice, 042 00, Slovak Republic. E-mail: matej.beres@tuke.sk, daniel.zencuch@student.tuke.sk

Purpose. The aim of the work is the design and creation of a modifiable closed-loop control system for DC to DC voltage regulation. Originality. The regulation parameters of modifiable close-loop control system can be easily change by proposed windows application. With such a system the regulation parameters can be easily determined without a calculation. Methodology. The paper as an example provides a description of a one DC to DC converter which belongs to buck-boost family. Presented converter is composed of two switching devices. For implemented a control strategy the galvanic isolated control signals technique was made to achieve desired control methodology. Control signals as well as the regulation itself was made by an ARM microcontroller type of STM32F103C8T6. Based on used MCU the control algorithm for voltage regulation was made. With such MCU the user interface where the whole system can be monitored and controlled was made also. The user interface is a windows application which was created with the help of a Visual Studio. Results. The paper provides the results achieved by the proposed control system. The results illustrated by windows application were compared with the oscillograms. From the results the incorrect regulation parameters can be easily spotted. Practical value. The advantage of such a control system is in the possibility of using it for various DC to DC converters where the regulation parameters can be easily determined without calculation. The user only connects the control signals to switching devices and connect the output voltage through voltage divider into the analogue input of the MCU. Disadvantage of the proposed system is, it can not be used without a PC where the windows application is running. Figures 15 , references 8.

Key words: control algorithm, close loop system, DC to DC converter, PI regulation.

\section{ПРОЕКТУВАННЯ ТА РЕАЛІЗАЦІЯ ЗМІНЮВАНОЇ ЗАМКНЕНОЇ СИСТЕМИ КЕРУВАННЯ ДЛЯ РЕГУЛЮВАННЯ DC-DC НАПРУГИ}

\section{М. Береш, Д. Женчух}

Технічний університет Кошице, Словаччина

вул. Лєтня, 9, м. Кошице, 04200, Словаччина. E-mail: matej.beres@tuke.sk, Daniel.zencuch@student.tuke.sk

Метою роботи є проектування та створення змінюваної замкнутої системи керування для регулювання DCDC напруги. Параметри регулювання змінюваної замкненої системи керування можуть бути легко задані за допомогою запропонованого додатка Windows. За допомогою такої системи параметри регулювання можна легко визначати без виконання попередніх розрахунків. У статті на прикладі подано опис DC-DC перетворювача, який належить до сімейства підвищуючих пристроїв. Представлений перетворювач складається 3 двох комутаційних пристроїв. Для реалізованої стратегії керування була створена техніка на основі гальванічно ізольованих сигналів керування для досягнення бажаної методології керування. Керуючі сигнали, а також саме регулювання здійснювалися за допомогою мікроконтролера ARM типу STM32F103C8T6. На основі використаного мікроконтролера створено алгоритм керування регулюванням напруги. За допомогою такого мікроконтролера було розроблено користувальницький інтерфейс, за допомогою якого можна контролювати $\mathrm{i}$ керувати роботою усієї системи. Інтерфейс користувача - це програма для Windows, що була створена за допомогою Visual Studio. Результати, отримані за допомогою Windows-додатку було порівняно $з$ реальними осцилограмами. На основі отриманих даних можна легко визначати невірні параметри регулятора. Перевага такої системи керування полягає у можливості іiї використання для різних DC-DC перетворювачів, де параметри регулювання можна легко визначити без розрахунку. Користувач лише подає керуючі сигнали до комутаційних пристроїв і підключає вихідну напругу через дільник напруги до аналогового входу мікроконтролерної системи. Недоліком запропонованої системи є те, що іï не можна використовувати без ПК під управлінням OC Windows.

Ключові слова: алгоритм управління, замкнена система, DC-DC перетворювач, ПI-регулювання.

PROBLEM STATEMENT. In present days, many closed-loop systems were created for many purposes such in [1-3]. The reason is that they can be useful in many applications. But many close-loop systems are mostly made for only one purpose. For example, for the motor speed regulation, the voltage regulation, the current regulation, etc. It is too hard or nearly impossible to find a closed loop system that can handle for example the motor speed regulation as well as the voltage regulation without changing the whole control system. Due of that the proposed close loop system was created that removes mentioned drawback. For limited range of the paper only one part of the system which take care of voltage regulation will be described. The DC motor regulation will be described in another paper. For achieving such a system, a microcontroller control unit (MCU) was considered. To be more precise the STM32F103C8T6 MCU. The main reason is that it can be easily modified, and in some cases, it can be cheaper than analog electrical components. 
As the title says the close-loop system is used. The close-loop system needs a feedback from the output of controlled device. In case of the voltage regulation the modified voltage value is connected to an analog input of the MCU. In case of the motor speed regulation a digital value from a digital encoder is connected to a digital input of the MCU. That is another reason to use the MCU. Following chapters briefly describe each part of the control system that handle voltage regulation.

Before the individual parts of the system will be described, it is always good to know how the conventional and discrete closed-loop system work.

EXPERIMENTAL PART AND RESULTS OBTAINED.

\section{Conventional vs discrete PI control}

The closed-loop system measures the output value and compare it with required value. If an error occurs the system provides changes to ensure that an error is zero or close to zero. For the sake of simplicity, the basic principle can be seen in the Fig. 1 .

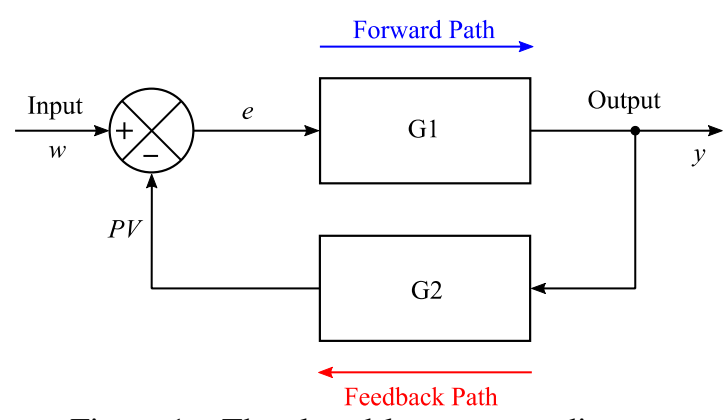

Figure 1 - The closed-loop system diagram

Where the G1 represents the open loop gain of the controller, which represents the forward path. The G2 represents a gain of the sensor, transducer, or measurement system in the feedback path. A transfer function of the closed-loop system can be simply determined by equation (1).

$$
\frac{\text { Output }}{\text { Input }}=\frac{y}{w}=\frac{G 1}{1+G 1 G 2} .
$$

The closed-loop control system can be created with the help of an analogue electrical components such as the operational amplifiers or with the digital electrical components such as the microcontrollers. The digital devices provide more accurate and more stable results than analogue devices. Therefore, the discrete regulation system was considered. Most common devices for such regulation are MCUs. But for better understanding it is good to know what the difference between conventional and discrete control system is.

Conventional PI control

The PI controller is the most popular variation. The value of the controller output $u(t)$ can be determined by the equation (2).

$$
y(t)=y_{\text {bias }}+K_{c} e(t)+\frac{K_{c}}{\tau_{I}} \int_{0}^{t} e(t) d t .
$$

The $y_{\text {bias }}$ is a constant which can be set to the value of $u(t)$. This constant gives smooth transfer if the error is zero in time when the controller is starting. $K_{c}$ represents gain constant of the controller and $\tau_{I}$ represent integral time constant. Higher value of $K_{c}$ makes the controller more aggressive in responding to the difference between required value and the measured value. The set point $(w)$ is required value and process variable $(P V)$ is the measured value. The error is the difference between required value and measured value which can be determined by the equation (3).

$$
e(t)=w-P V .
$$

Discrete PI control

Digital controllers are implemented with discrete sampling periods and a discrete form of the PI equation is needed to approximate the integral of the error. This modification shown in the equation (4) replaces the continuous form of the integral with a summation of the errors and uses $\Delta t$ as the time between sampling instances and $n_{t}$ as the number of sampling instances.

$$
y(t)=y_{\text {bias }}+K_{c} e(t)+\frac{K_{c}}{\tau_{I}} \sum_{i=1}^{n_{t}} e_{i}(t) \Delta t .
$$

It is not the goal of this paper describing such controller. The literatures [4-6] provides more information about discrete PI controllers.

The main goal of the proposed control system is that it can be used for controlling of various DC motors as well as DC to DC converters. But, to verify this statement, at least one DC to DC converter and one DC motor control should be tested. Both actuators should be handled by the same MCU. But each actuator provides a different feedback signal form. Therefore, the next chapters not only briefly describe used actuator, but also the way how the signals forms from actuator are processed by the MCU.

To achieve the correct function of the control system the control unit must know the actual value of actuators output. Actuators values misinterpretation can lead to wrong behaviour of the control system. It can also lead to damage the whole system. Therefore, the following chapters briefly describes the way of a control strategy as well as the proposed hardware solution for each part of the control system. For example, the next following chapter briefly describes a voltage control strategy of the DC to DC converter with the help of the MCU.

DC to DC pulse converter topology, control signals and voltage regulation

In case of the DC to DC converters the output voltage value can be easily adjusted by connecting two resistors as dividers and one Zener diode for overvoltage protection. The Fig. 2 shows the DC to DC converter schematic that was used for test purposes. This type of the converter can be used in interleaved connection where it can be working with higher efficiency. Also, the number of branches can be change based on measured efficiency [7]. 


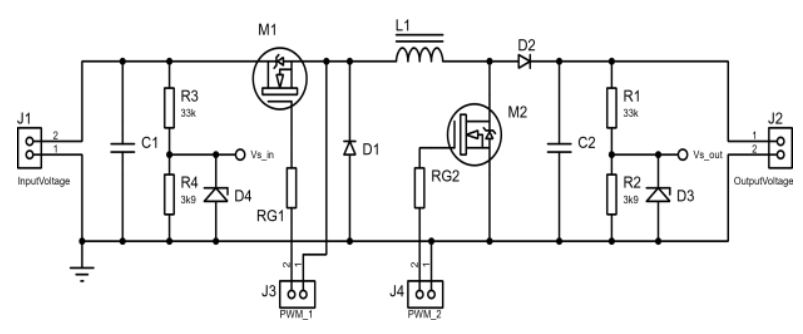

Figure 2-DC to DC converter schematic

Based on the schematic the PCB (Printed Circuit Board) was created as can be seen in the Fig. 3. The PCB was designed in the way where all power semiconductor components are on the one side. With proposed design, only one heatsink was used as can be seen in the Fig. 4.

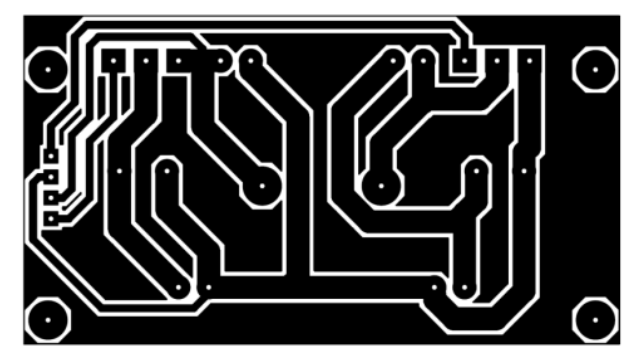

Figure 3 - Proposed PCB of DC to DC converter based on proposed schematic

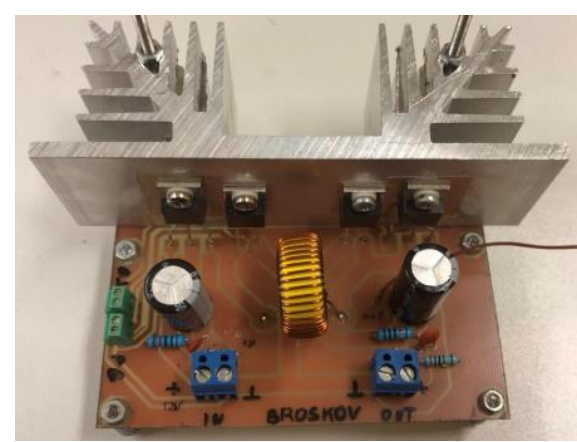

Figure 4 - Implemented DC to DC converter based on proposed PCB

As it can be seen in the Fig. 2, the cascaded DC to DC converter is used. This kind of converter belongs to buck-boost family of DC to DC converters and it can be controlled by two methods. The first method is when both transistors are controlled by the same control signal. In this case the output voltage can be lower or higher based on the duty cycle width which can be determined by following equation (5).

$$
V_{\text {out }}=V_{\text {in }} \frac{D}{1-D} \text {. }
$$

The disadvantage of such a control method is in a stability and in shorter control range for both modes (buck and boost). Thus, the first half of the duty cycle width is for the buck mode end the second half of the duty cycle width is for the boost mode. Of course, the second half of the duty cycle width has its limitation due to the operation principle of the boost converters [8].

The second control method removes drawbacks mentioned above. This method lies in creating two independent control signals for each transistor. Thus, for example the first control signal is connected to the first transistor which switch on and off the current from input power source, and the second control signal is connected to the second transistor which shorts the right side of the inductor. Basically, for the buck mode the first control signal drive first transistor with a variable duty cycle width when the second control signal is always off, and for the boost mode the first control signal is always on when the second control signal drives transistor with variable duty cycle width. This kind of control method has its drawback in creating two independent control signals. But, in present days the cheap MCUs have more than enough capabilities for creating such control signals. With the second control method, both modes can be used in much wider duty cycle width range, therefore more precise voltage regulation can be achieved for each mode. Due to that the second control method was considered and applied to the MCU.

As a brain of the system for voltage regulation and control signal generation the development board of STM32F103C8T6 was applied. The development board is illustrated in the Fig. 5. Programming such an MCU was made with the help of a CubeIDE software. To connect MCU with the PC the ST-link V2 was used.

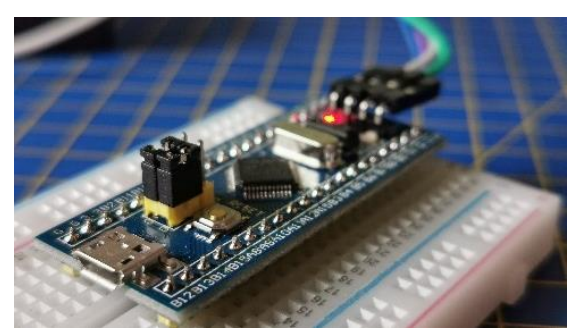

Figure 5 - STM32F103C8T6 development board

The control signals created by the MCU are connected to the transistor gates via the galvanic isolated MOSFET drivers. Whatever happen to power transistor the MCU will be safe. This is the first reason why the galvanic isolation of control signals is used. The second and more valid reason is because of the boost mode and possibility of switching transistor on the high side of the power supply. In boost mode (for this topology, Fig. 2) the converter's first transistor should be always on to ensure boost mode for full range of duty cycle width for the second transistor. With a conventional MOSFET driver it cannot be done. Because the conventional MOSFET drivers do not work for a high side transistor in full range of duty cycle range. The proposed galvanic isolation of control signals for the converter can be seen in the Fig. 6. In this case, two same galvanic isolated MOSFET driver waw used. 


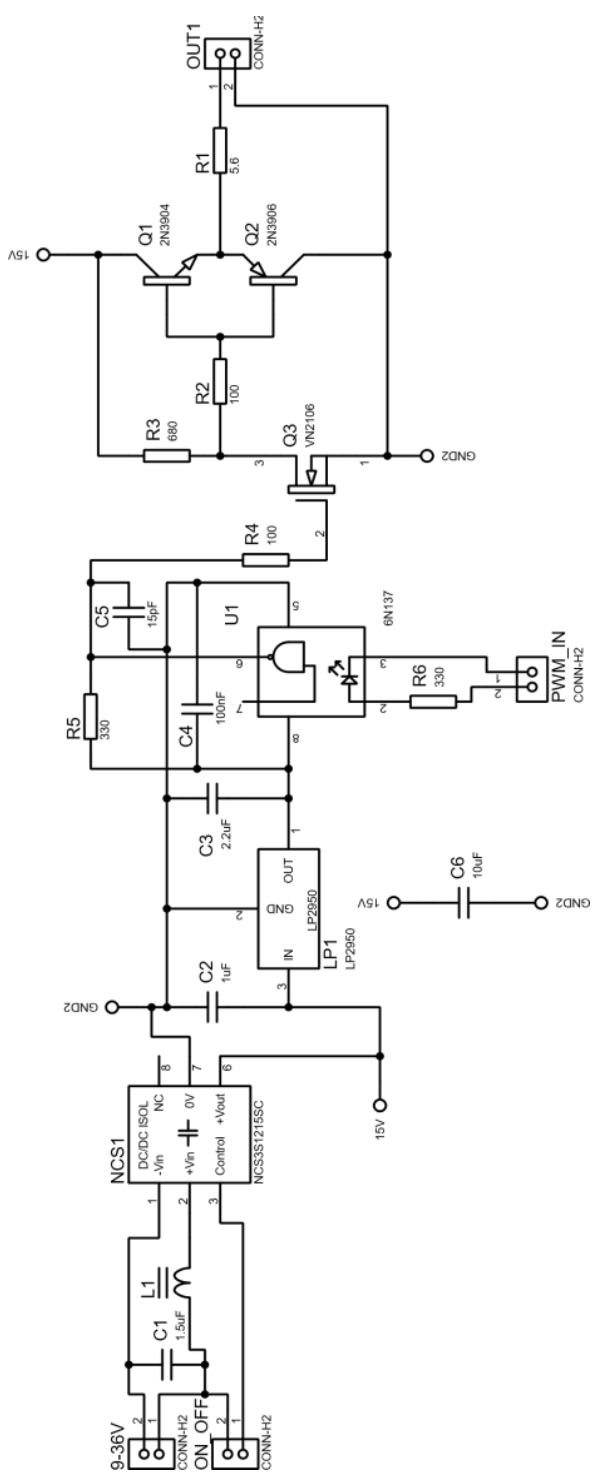

Figure 6 - The schematic of the proposed galvanic isolated MOSFET driver

Based on the schematic the PCB (Printed Circuit Board) was created as well as a real model as can be seen in the Fig. 7. The PCB was created with the help of UV light. Basically, the proposed PCB was printed on the transparent foil which was placed on the PCB with a positive photosensitive layer. Then the $\mathrm{PCB}$ with the template on the top was exposed to UV light. The UV light makes parts which were covered by printed lines softer. The sodium hydroxide removes the softer parts. In this state the PCB was ready to be placed into ferric chloride where it removes copper parts which are not covered with the photosensitive layer.

The control signals are created with the help of one timer which consist of several registers. With the correct registry settings, in this case, two channels of the timer can be set as the PWMs. These two channels as it was mentioned before are in the next connected via proposed MOSFET drivers to the transistor gates. The way of PWM signal generation is very well known and therefore it will not be described furthermore.
The feedback (analogue voltage signal) from the converter is connected from the converter pin name Vs (Voltage signal) to the analogue input of the MCU. The MCU converts analogue voltage values into a digital form which is understandable for the MCU. The digital form which represents the output voltage of the converter, helps a control algorithm to set the right value for a compare register which represents the duty cycle width. The term right value means the value which is the result of a calculation from required value and actual value. The whole algorithm is illustrated in the Fig. 8.
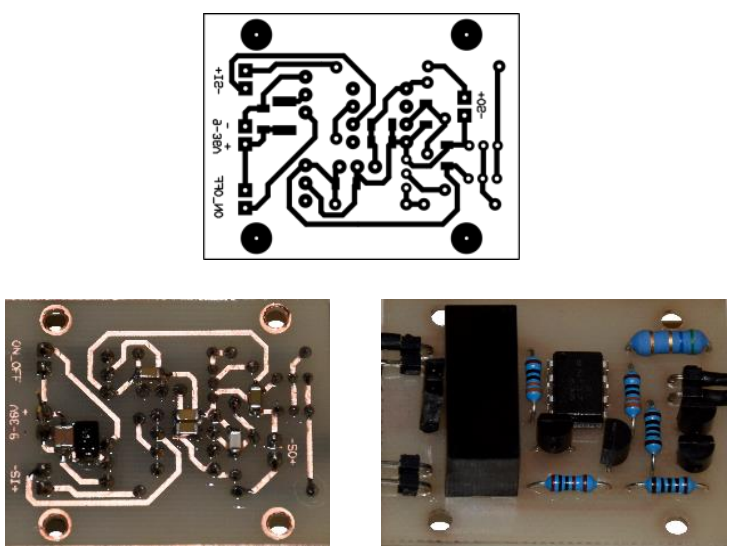

Figure 7 - PCB of proposed MOSFET driver for one transistor

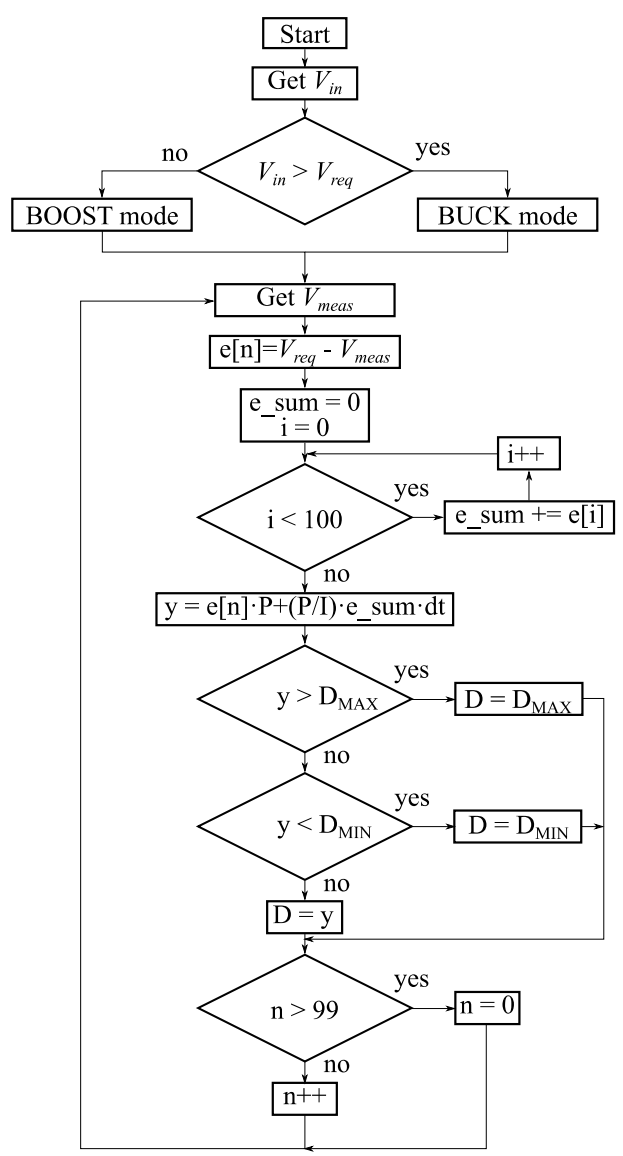

Figure 8 - Control algorithm for voltage regulation of DC to DC converter 
Firstly, the control algorithm checks if the input voltage is higher or lower than the required voltage. Base on this information the MCU change the mode. In case when the input voltage is higher than the required voltage, the MCU set the control signals for BUCK mode. In case when the input voltage is lower than the required voltage the MCU set the control signals for BOOST mode. As can be seen in the Fig. 7, the control algorithm uses a summation which consist of one hundred regulation errors. It represents the delay (integration) of PI regulator, because the regulator will provide duty cycle changes until the one hundred summation of errors will be close to zero. Which takes some time, and it corresponds the time when the measured value (output voltage of DC to DC converter) will be close to the required value. The required voltage value as well as the measured voltage value is presented in a digital form. That removes the error which occurs during calculation of the digital value to the real voltage value. Based on used voltage divider and MCUs 12-bit AD converter, the digital voltage value $V_{\text {digit }}$ can be calculated as follows (6).

$$
\begin{gathered}
V_{\text {digit }}=\frac{A D C_{\text {resolution }}}{A D C_{\text {reference_voltage }}} V_{s_{-} \text {out }} ; \\
V_{s_{-} \text {out }}=V_{D C-D C_{-} \text {out }} \frac{R_{2}}{R_{1}+R_{2}} .
\end{gathered}
$$

$A D C_{\text {resolution }}$ is a quantization number of the 12-bit $\mathrm{AD}$ converter, which is 4095 . The $A D C_{\text {reference_voltage }}$ is the reference voltage of ADC converter, which in this case is $3.3 \mathrm{~V}$.

If it is needed a real output voltage value of the converter can be back calculated from the digital value as follows:

$$
V_{\text {real }}=\frac{V_{\text {digit }} \cdot A D C_{\text {reference_voltage }}}{A D C_{\text {resolution }}} \frac{R_{1}+R_{2}}{R_{2}} .
$$

Last but one part of the control algorithm prevents oversaturated calculated result to be written in to compare registers. Basically, this part of the control algorithm helps clamp calculation results to suitable range. Because the compare register does not handle the negative values as well as the values that are higher than the maximum.

For ability of using a wider range of the DC to DC converters the maximum value of duty cycle in digital form can be modified. Changing the maximum value which is done by an ARR (Auto Reload Register), determine the output frequency of the PWM signal. Applied MCU has 32-bit timer either, but in this case the 16-bit timer is more than enough. The MCU clock speed is $72 \mathrm{MHz}$, which can be directly connected into the timer which handle PWMs. Base of the clock speed and the timer resolution the ARR register for required PWM frequency can be easily calculated (8).

$$
A R R=\frac{F_{-} C P U}{f_{P W M}}-1 .
$$

The constant of -1 is required for a reason. The reason is that the timer set zero value in its counter every time the top value (ARR) occurs. The zero state in the counter takes a same time as non-zero value. Therefore, the one increment value must be subtracted to achieve precise output frequency.

As it will be mentioned later the frequency as well as required voltage value can be sent to $\mathrm{MCU}$ via serial interface from the proposed windows application. The MCU subsequently change require voltage or PWM frequency. Following chapter briefly describes the proposed windows application.

Proposed Windows application and results

Sonner as the windows application will be described, it is good to mention the goal about what the application should do. The application should be capable of giving the commands to the MCU as well as take an information from it. Basically, the manual control capability. In this case the MCU should send an information about the current duty cycle value of each timer channel, the output voltage of DC to DC converter, the $P$ parameter, the $I$ parameter and the current frequency of PWMs. On the other hand, the windows application should be able to send the regulation parameters, the required voltage, the required frequency, and start-stop commands. The data from the MCU should be updated with the frequency of $100 \mathrm{~Hz}$. This helps to create the time dependent graphs as it will be illustrated later. The commands from the windows application are only sent to MCU when the specific buttons will be pressed.

The proposed windows application was created with the help of a Visual Studio. An introductory window is shown in the Fig. 9. A communication between the MCU and the window application is provided by asynchronous serial interface (UART).

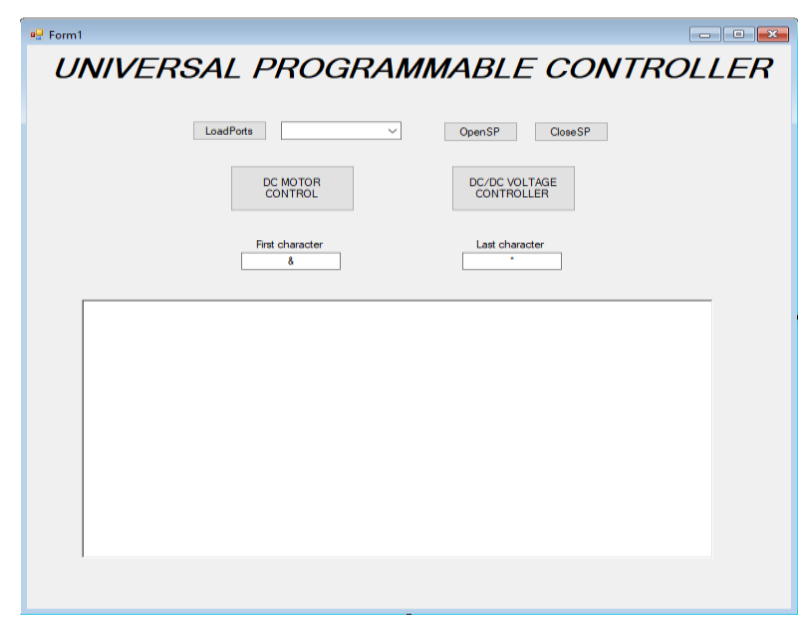

Figure 9 - Introductory windows of proposed windows application

As it can be seen in the Fig. 9, the introductory windows contain a connection setting, the mode buttons, and a serial monitor window. The connection setting helps user to pick and open or close the right serial port. The serial monitor window is only for administrative purposes. It shows received and 
transmitted data from the opened serial port. The not usual transmitting way is that each command contains two special characters. The first character is before the command and the second character is behind the command. This kind of communication ensures that the MCU or the windows application does not do anything until the end special character is received. This prevents the MCU or the windows application from a crashing or doing unpredictable thinks. For example, if the windows application sends commands to the MCU to change PWM frequency, the MCU because it is the asynchronous communication with set interrupts will make changes for each received character. In a case when the characters are buffered the MCU does not know which data are new and which are not. This can lead to showing or setting parameters wrongly. Therefore, the special characters are involved.

The mode buttons serve to pick users desired mode. The windows application was created to handle motor speed regulation and the voltage regulation of DC to DC converters. In this paper only the DC to DC converter mode will be presented where the basic setting can be made. Proposed window for DC to DC converter voltage regulation is illustrated in the Fig. 10.

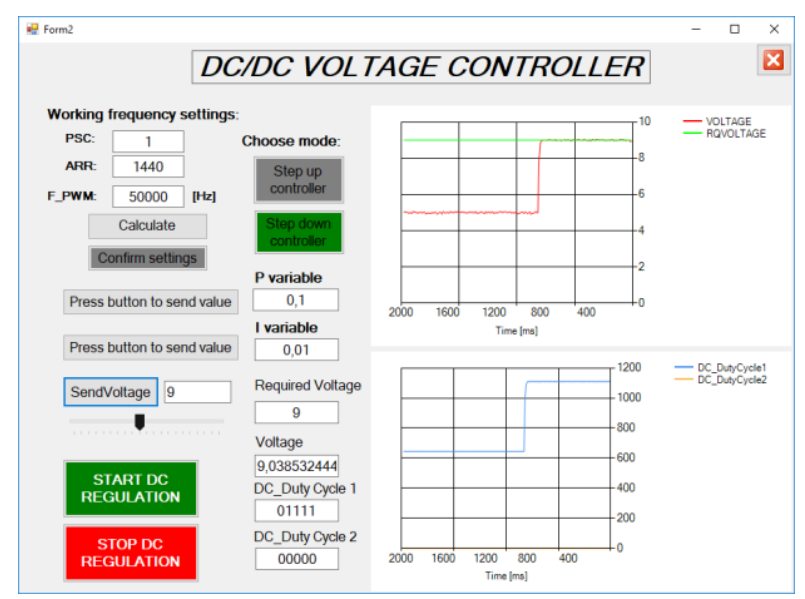

Figure 10 - Proposed window for DC to DC controller voltage regulation mode

Because the goal of this paper is not describing how the windows application can be created, only the function of important parts will be described furthermore. The window can be divided into several parts. The first part is frequency setting. This part of the window shows the user an actual frequency of PWMs. The frequency can be changed by two methods. The first method is in writing prescaler and ARR value, which are the values of timer registers. The prescaler value divides the CPU clock before the timer. It helps to obtain the lower frequency of PWMs. The second method for frequency changing is writing the frequency value in hertz. After pushing the button "calculate" the ARR value and the prescaler will be calculated. After pressing the "Confirm setting" button the windows application sends data to the MCU which process incoming data and set the timer to the required frequency.

The second part of the window provides an information about mode the DC to DC converter is. Also, these modes can be easily changed by the user pressing the appropriate button. As it was mentioned in proposed algorithm the control program checks the input voltage and required voltage. Based on these parameters the control algorithm picks a suitable mode (buck or boost).

The third part of the window shows the regulation parameters $(P$ and $I)$. These regulation parameters can be changed by user during a time when the converter operates. After changing the text box by entering the appropriate parameter, pressing the button on the left side of text box sends entered parameter into the MCU.

The fourth part of the window is for required voltage setting to be regulated by the converter. The required voltage can be set by two methods. The first method is by entering the value in the text box and the second method is by moving a slider. By the slider moving the value in the text box is dynamically changed and the voltage value is always the integer. If the non-integer value is required, the first method should be used.

The fifth part of the window consists of two charts. The first chart provides time dependent waveforms of the required voltage and the measured voltage. The measured voltage waveform provides to user how the converter works with applied regulation parameters. The results about how it is useful will be presented later. The second chart provides time dependent waveforms of duty cycle width for each timer channel. In this part of the window four text box which represents the values illustrated in charts are included too.

The last part of the application window are buttons which activate or deactivate the voltage regulation process.

With such a proposed windows application it can be easily determined if the regulation parameters are correct. Also, the advantage of such a system is that the user can see how the regulation behave the whole time. Based on the proposed control strategy as well as the proposed windows application the next subchapter shows achieved results.

Achieved results

To verify the correctness of the proposed control system, the oscilloscope time dependent waveforms were made. Oscilloscope waveforms show the output voltage of the DC-DC converter. The same waveforms are illustrated in the proposed windows application. As first the following figures illustrate the difference between good and bad regulation parameters settings.

In case when the proportional value is too high, the Fig. 11. shows that the output voltage of the DC to DC converter creates an overvoltage spike, which can damage a connected load. The overvoltage spike can 
be spotted by the windows application also (right side of the figure). The overvoltage spike in the windows application is less recognizable because of fewer samples per second are made by the MCU than by the oscilloscope and the MCU create mean value from 10 values of $\mathrm{ADC}$ to prevent converter to take an action on every voltage spikes that are created by the converter.

Another example, when the proportional parameter is incorrectly set is illustrated in the Fig. 12. This time the required voltage value will never be achieved. The reason is that the proportional parameter is high, and the controller will always make over actions in changing the duty cycle value. Therefore, the output voltage is oscillating.

From presented oscillogram and graphs from the windows application it can easily spot that the regulation parameters are incorrect. In case when the user does not have an oscilloscope, the user application can be extremely useful. The chart in the windows application also illustrates the time dependent duty cycle width.

In case when the integration parameter is high the time is longer when the output voltage reaches the required voltage is clearly recognizable as it can be seen in the Fig. 13.
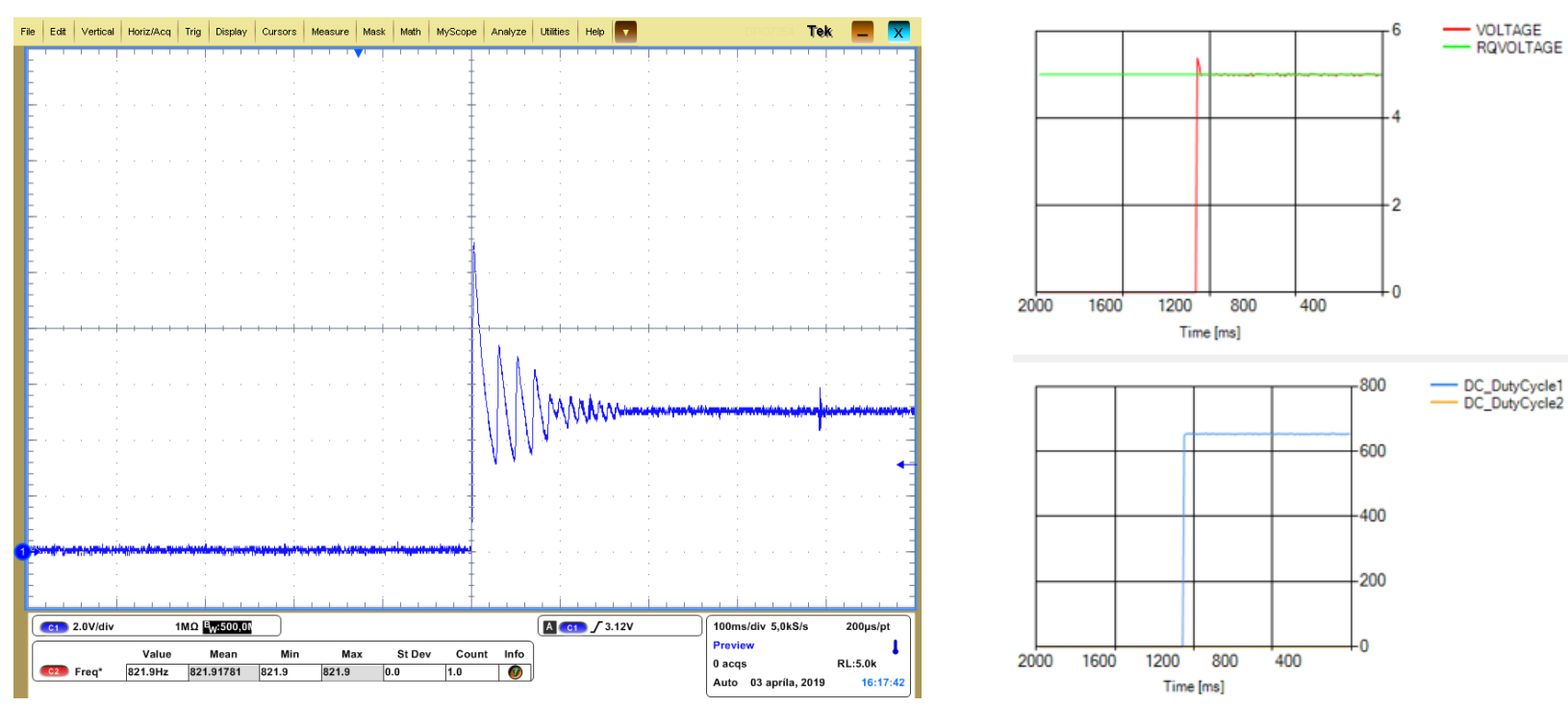

Figure 11 - Overvoltage spike created by high value of proportional parameter
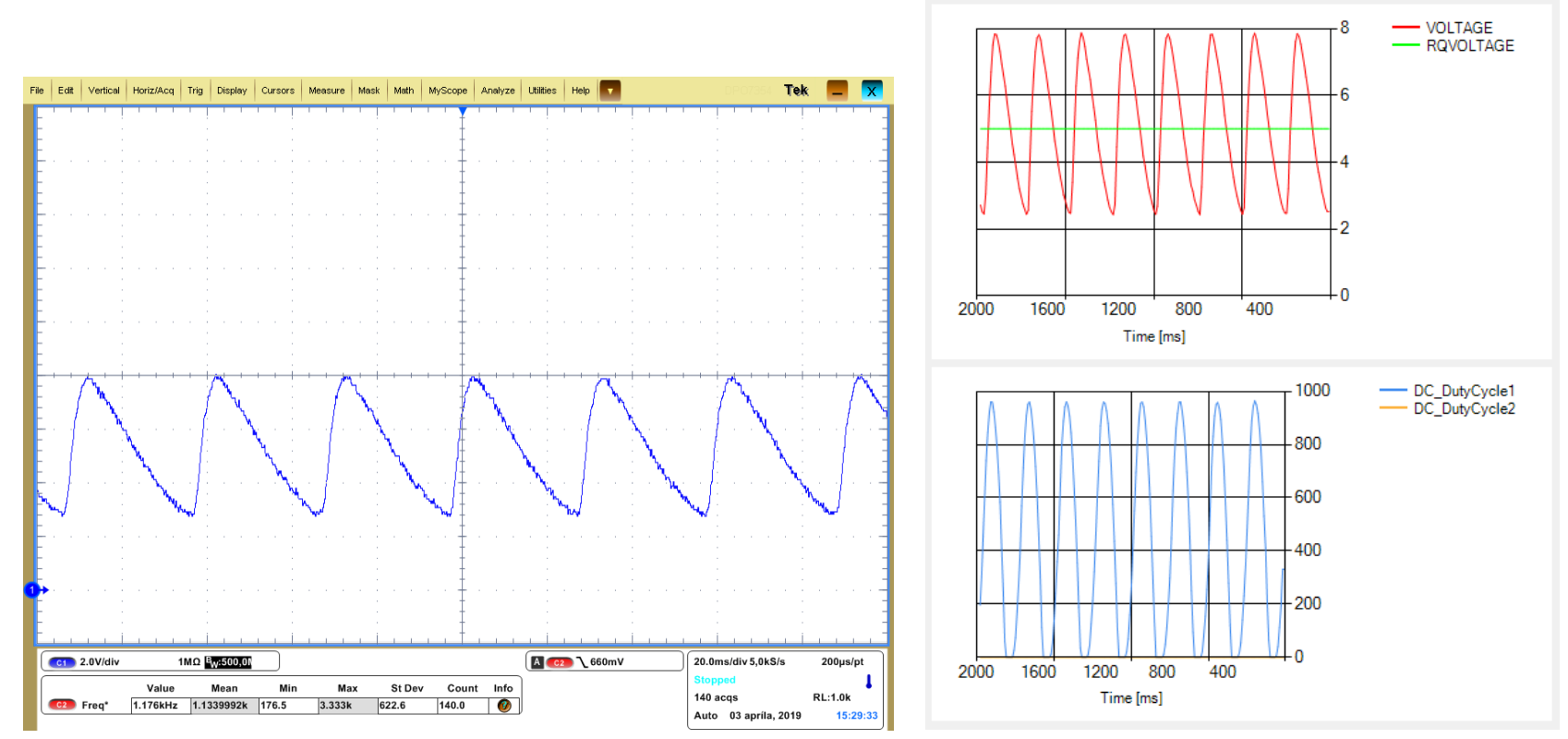

Figure 12 - Voltage oscillation due to high proportional value 

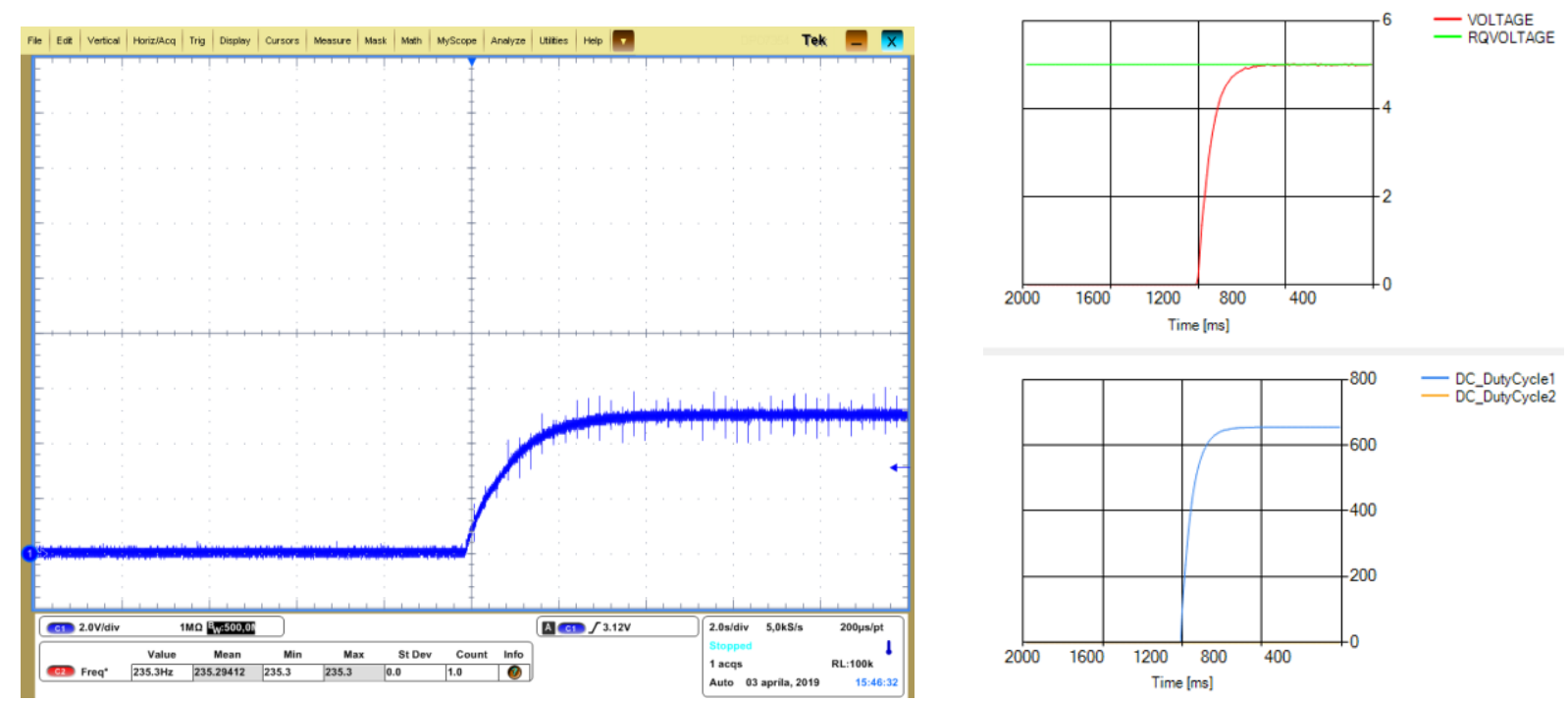

Figure 13 - Output voltage reaches the required voltage with a high integration parameter

With the correct settings of regulation parameters, the results can be seen in the Fig. 14. From previous illustrated results achieved by the windows application it is clearly seen that they correspond to results illustrated by the oscilloscope. Therefore, the following results will not consist of the oscillograms.
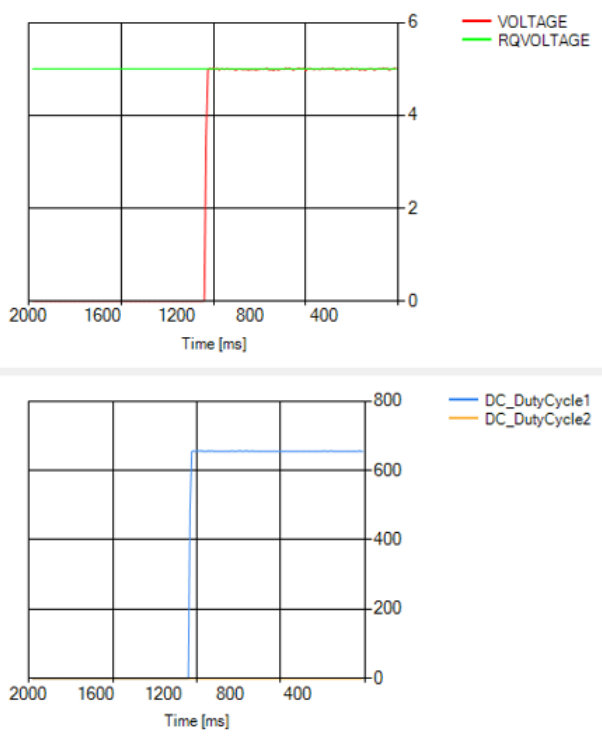

Figure 14 - Output voltage of the converter when with correct setting of regulation parameters

From presented results the regulation parameters can be easily to determine without calculating. All previous results were in buck mode. In case when the required voltage of the converter should be higher than voltage connected at the input of the converter, the boost mode is used. The boost mode as it was mentioned before, use the second way of controlling transistors. The way, when the transistor on the high side is always closed and the transistor which short one side of the inductor to the ground to accumulate energy in it is switching. The results made in boost mode are illustrated in the Fig. 15.

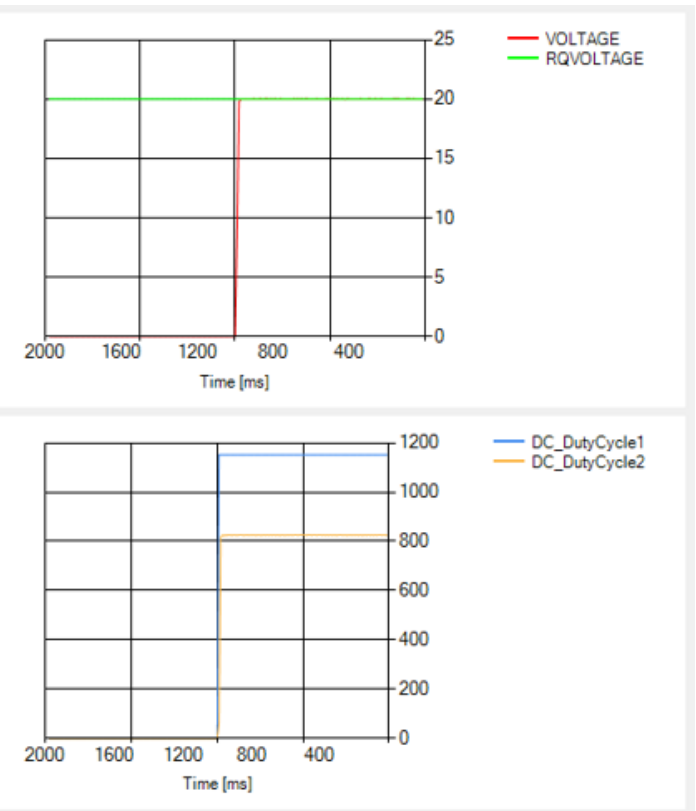

Figure 15 - Voltage regulation waveforms in boost mode

CONCLUSION. Proposed windows application as well as control strategy can be useful in determining the regulation parameters without calculating them. The proposed windows application, chosen $\mathrm{MCU}$ and galvanic isolated control signals can be applied to most of the DC to DC converters. Such a control system can be also especially useful in education purposes where the regulation parameters can be modified during regulation process. In this case the student can quickly recognize if the regulation parameters are correctly set. The proposed system can be improved by using some cover and touchscreen. 


\section{REFERENCES}

1. S. Li, D. Gan, \& H. Xu (2019). Closed-Loop Load Model Identification Using Small Disturbance Data, 2019 International Conference on Smart Energy Systems and Technologies (SEST), Porto, Portugal, 1-6, DOI: 10.1109/SEST.2019.8849073.

2. M. Di Maio et al. (2018). Interface Management with Closed-Loop Systems Engineering (CLOSE), 2018 IEEE International Systems Engineering Symposium (ISSE), Rome, 1-8, DOI: 10.1109/ISSE43632.2018.9058620.

3. W. Yafei (2017). Bifurcation analysis of closedloop system for a fixed-trim vehicle, 2017 29th Chinese Control And Decision Conference (CCDC), Chongqing, 1691-1696, DOI: 10.1109/CCDC.2017.7978789.

4. El Moucary, Chady, et al. (2018). Complete Design of a Hardware and Software Framework for PWM/Discrete PID-Based Speed Control of a Permanent-Magnet DC Motor Without Prior Knowledge of the Motor's Parameters. Recent Trends in Computer Applications. Springer, Cham, 153-173.
5. Wu, Xuanlyu, et al. (2018). Simplified discretetime modeling and dynamic characteristics analysis of PI-controlled voltage source inverter. Applied Power Electronics Conference and Exposition (APEC), IEEE, 2914-2917.

6. Khan, Pathan Fayaz, et al. (2018). Design and Implementation of a Discrete-Time Proportional Integral (PI) Controller for the Temperature Control of a Heating Pad. SLAS TECHNOLOGY: Translating Life Sciences Innovation, 2472630318773697.

7. D. Kováč et al. (2018). Circuit elements influence on optimal number of phases of DC/DC buck converter. Electronics Letters, 54, 7, 435-437, DOI: 10.1049/el.2018.0043.

8. V. Michal (2016). Dynamic duty-cycle limitation of the boost DC/DC converter allowing maximal output power operations, 2016 International Conference on Applied Electronics (AE), Pilsen, 177-182, DOI: 10.1109/AE.2016.7577268.

\section{ПРОЕКТИРОВАНИЕ И РЕАЛИЗАЦИЯ ИЗМЕНЯЕМОЙ ЗАМКНУТОЙ СИСТЕМЫ УПРАВЛЕНИЯ ДЛЯ РЕГУЛИРОВАНИЯ DС-DС НАПРЯЖЕНИЯ}

\section{М. Береш, Д. Женчух}

Технический университет Кошице

Летна, 9, 042 00, Кошице, Словакия. E-mail: matej.beres@tuke.sk, Daniel.zencuch@student.tuke.sk

Целью работы является проектирование и создание изменяемой замкнутой системы управления для регулирования DC-DC напряжения. Параметры регулирования изменяемой замкнутой системы управления могут быть легко заданные с помощью предлагаемого приложения Windows. C помощью такой системы параметры регулирования можно легко определять без выполнения предварительных расчетов. В статье на примере дано описание DC-DC преобразователя, который принадлежит к семейству повышающих устройств. Представленный преобразователь состоит из двух коммутационных устройств. Для реализуемой стратегии управления была создана техника на основе гальванически изолированных сигналов управления для достижения желаемой методологии управления. Управляющие сигналы, а также само регулирования осуществлялись с помощью микроконтроллера ARM типа STM32F103C8T6. На основе использованного микроконтроллера создан алгоритм управления регулированием напряжения. С помощью такого микроконтроллера был разработан пользовательский интерфейс, с помощью которого можно контролировать и управлять работой всей системы. Интерфейс пользователя - это программа для Windows, которая была создана с помощью Visual Studio. Результаты, полученные с помощью Windows-приложения сравнивались с реальными осциллограммам. На основе полученных данных можно легко определять неверные параметры регулятора. Преимущество такой системы управления заключается в возможности ее использования для различных DC-DC преобразователей, где параметры регулирования можно легко определить без расчета. Пользователь лишь подает управляющие сигналы к коммутационным устройств и подключает выходное напряжение через делитель напряжения к аналоговому входу микроконтроллерной системы. Недостатком предложенной системы является то, что ее нельзя использовать без ПК под управлением OC Windows.

Ключевые слова: алгоритм управления, замкнутая система, DC-DC преобразователь, ПИ-регулирование.

Стаття надійшла 21.05.2021. 